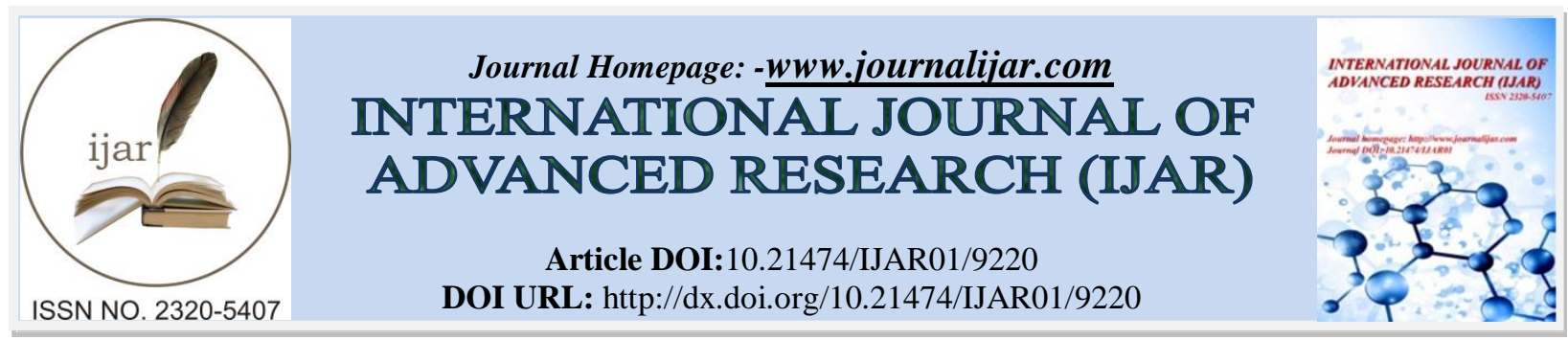

RESEARCH ARTICLE

\title{
MODEL FOR IMPROVING THE IN-ROLE PERFORMANCE OF PRIVATE LECTURERS IN INDONESIA.
}

\author{
Muhammad Akhsan Tenrisau ${ }^{1}$, Siti Haerani ${ }^{2}$, Haris Maupa ${ }^{2}$ And Muhammad Ismail Pabo ${ }^{2}$. \\ 1. Department of Management, STIE NOBEL Indonesia Makassar, Indonesia. \\ 2. Faculty of Economics and Business, Hasanuddin University, Indonesia.
}

\section{Manuscript Info}

Manuscript History

Received: 06 April 2019

Final Accepted: 08 May 2019

Published: June 2019

Key words:-

psychological empowerment, job involvement, effort, in-role performance, organizational behavior, human resource strategies, higher education.

\begin{abstract}
The main objective of this study is to develop a model for improving in-role performance of lecturers by examining the linkage between psychological empowerment and job involvement on lecturers' in-role performance both direct and indirect through effort at private universities in South Sulawesi, Indonesia. The sample size for the study comprised 307 who already possessed professional lecturer certificates from 20 private universities in South Sulawesi. Data were processed using the Partial Least Square (PLS)-Structural Equation Modeling (SEM). Results of data analysis confirm the hypotheses drawn from the literature. Consistent with other studies, the results of this study confirm that psychological empowerment, job involvement and effort positively and significantly influence in-role performance. Furthermore, effort positively and significantly mediates the relationship between psychological empowerment and in-role performance. However, effort does not mediate the relationship between job involvement and in-role performance.
\end{abstract}

Copy Right, IJAR, 2019,. All rights reserved.

\section{Introduction:-}

Constitution of the Republic of Indonesia Number 12 of 2012 concerning Higher Education states that Universities as part of the national education system have a very large and strategic role in developing human resources and increasing national competitiveness. Lecturers as part of the universities' human resources, are the implementer of the Tridharma of Higher Education (teaching, research and community services) should have superior quality so that the strategic and large role can be run as expected.

A high quality lecturer is one of the factors that have an important role in contributing to the achievement of the vision, mission and goals of a university. Therefore, every lecturer is required to always improve themselves and improve their performances regardless of the various obstacles they faced. Lecturer performance is a form of human resource actualization, so ideally a professional lecturer must show good performance.

One of the classic problems of higher education in Indonesia is the qualifications of lecturers who have not met the requirements, namely a minimum of master degree and also the number of doctorate graduates who are still very lacking. Law of the Republic of Indonesia Number 14 of 2005 concerning Teachers and Lecturers requires that a lecturer must possess a master degree. But the facts show the opposite. Based on data from Ministry of Research, 
Technology and Higher Education of the Republic of Indonesia, out of a total of 8,859 lecturers there are still lecturers who still hold a Bachelor degree which are 2,203 people $(24.87 \%), 5,849$ people hold Masters degrees $(66.02 \%)$ and only 807 people hold Doctoral degrees $(9.10 \%)$. While a minimum of 25 percent of doctorate degree is needed in order to improve the quality of higher education (Dhani, 2017).

The low qualifications of lecturers will affect the performance of lecturers. Safari (2015) revealed that lecturer qualifications, one of which is indicated by diploma ownership, educational background, knowledge and skills and work experience, contribute significantly to the performance of lecturers.

Table 1:-Number of research and community services grants of private lecturers in South Sulawesi (DIKTI FUNDS)

\begin{tabular}{|r|r|r|}
\hline Year & Research & Community Service \\
\hline 2018 & 408 & 169 \\
\hline 2017 & 474 & 143 \\
\hline 2016 & 341 & 187 \\
\hline 2015 & 404 & 145 \\
\hline
\end{tabular}

Source: LLDIKTI Area IX (2018)

Based on table 1 above, it appears that the number of research grants conducted by individuals and groups of private lecturers in South Sulawesi - which is one indicator of lecturer performance - shows that the number of studies is still very low. Data from the last four years shows that there is still a lack numbers of South Sulawesi' lecturers who receive research funding from the Directorate of Research and Community Service. The community service activities carried out by private lecturers in South Sulawesi in the last four years also show conditions that are far from encouraging.

Various problems faced by the lecturers above can be caused by external and internal factors (Uwes, 2003). To better understand the problems of the lecturer, a study needs to be held mainly related to internal factors, in this case the job attitude of the lecturer. Although job attitudes are assumed to be related to the in-role job performance, the results of past research in general have not shown a consistent relationship. The job attitude referred to in this study is psychological empowerement, work involvement and effort. The results of different studies indicate inconsistencies from the relationship between job attitudes and in-role job performance.

One of the main focuses of job attitudes in this research is psychological empowerment. In the last decade, the concept of psychological empowerment towards academics and staff began to be known in the context of higher education (Ahadi \& Suandi, 2014). This is due to its benefits for academics, staff and also universities (Short \& Johnson, 1994). Psychological empowerment involves the beliefs of lecturers about the meaning of their work, the ability to do their jobs well, beliefs in self-determination and their autonomy in influencing work outcomes (Spreitzer, 1995).

At present, the results of the studies of the relationship between psychological empowerment and in-role performance are inconsistent. For example, Liden et al. (2000) used a four-dimensional structure of the scale of psychological empowerement developed by Spreitzer (1995) to study how the four dimensions influence in-role performance, and found that self-efficacy had a significant positive impact on in-role performance. However, Dewettinck, et al. (2004) found that psychological empowerement can improve employee job satisfaction, but the impact on in-role performance is not clear.

Likewise, the results of studies that examined the relationship between job involvement and performance also showed inconsistent results. In general, job involvement is considered to have an important influence on individual and company performance results (Lawler, 1986), but the results of Brown's (1996) meta-analysis study show that work involvement does not stimulate the level of significance of employee performance directly. In contrast, empirical studies from Blau (1993); Brown and Leigh, (1996) and Gardner, et al., (1989), found a positive relationship between work involvement and performance. Brown and Leigh (1996) state that work involvement is more likely to influence performance indirectly through other variables, such as effort . 
The basis for this study is some contradictions of: concepts, understanding, focus of study, and results of past research on the influence of job attitudes on in-role performance with effort as a mediator. Lloyd (2008) emphasized in the implications of his study that effort has a significant role in the domain of performance. According to him, the development of performance theory will get benefits by including effort, and in-role performance. Benefit of effort is because this construct is not specific to a particular job but applies to each role (Morrison, 1994). Efforts are often associated with productivity and are increasingly being used as leverage points in HRD interventions (Shuck, Reio JR, and Rocco, 2011).

Although Brown and Leigh (1996) included variable effort as a mediation of performance, the study included only one job attitude, namely job involvement. Suryaman's study (2018) which examined the relationship of leadership, motivation, job satisfaction, and organizational commitment to the performance of private lecturers in Banten Province did not include effort into the research model. Therefore, this study differs from previous studies, because it integrates two work attitudes (psychological empowerment and work involvement) which are most often considered in the similar studies. Thus, this study that considers how psychological empowerment and job involvement effect in-role performance which mediated by effort is the first time done, especially in the context of private universities in Indonesia.

\section{Literatur Review Psychological empowerment}

The concept of empowerment in the 1990s was used in various fields of study such as psychology, management, business, health, community and education. Empowerment is a construct that can be used in various fields, such as economics, management, education and psychology, community development, and social movement studies.

Conger and Kanungo (1988) define empowerment as a process to increase feelings of self-efficacy among organizational members by identifying and eliminating conditions that foster powerlessness, both by the practice of formal organizations and informal techniques in providing information related to efficacy. According to Echiejile (1994), empowerment helps employees to have control over their responsibilities with sufficient confidence in carrying out their duties at work.

Short and Rinehart (1992) focus on identifying components of empowerment in educational institutions with the aim of developing appropriate instruments for participants in empowerment in educational institutions. As identified by Thomas and Velthouse (1990), psychological empowerment consists of four cognitions, namely, impact, competence, decision making and meaning. However, because the educational context differs from business, Short and Rine Hart (1992) propose psychological empowerment in the context of education. They explained that psychological empowerment in the context of education depends on six dimensions. These dimensions are autonomy, professional growth, status, self-efficacy, impact, and decision making.

The main assumption of empowerment theory is that empowered individuals or groups must have better performance than those who are relatively less empowered (Thomas \& Velthouse 1990). Thomas \& Velthouse (1990) specifically argue that empowered individuals should show proactive behavior characterized by flexibility, initiation, endurance, and perseverance. From this motivational perspective, the relationship between empowerment and performance is increasingly evident. Therefore, the theoretical expectation that psychological empowerment leads to high performance is reasonable.

Academics who have control over their teaching and are active in decision-making processes related to curricular, instructional and organizational issues generally consider themselves empowered (Short \& Johnson, 1994; Hawks, 1999). Academics in higher education need high autonomy (Moses, 2007). This autonomy arises from social contracts and in higher education, academics gain this autonomy through academic freedom, peer review, and joint governance. This autonomy also increases job satisfaction, effectiveness and performance (Phillips, et al. 2010). In addition, performance can be improved when academics are given autonomy over how their work must be completed (Miller \& Monge, 1986).

\section{Job Involvement}

The concept of job involvement was first introduced by Lodahl and Kejner (1965), and received a lot of attention because it was in the field of organizational behavior and work psychology. Job involvement can be described as the extent to which a person's performance influences his self-esteem (Lodahl and Kejner, 1965). Job involvement is 
the internalization of values about the goodness of work or the importance of work in the individual. With a higher level of job involvement, individuals will spend more time and effort on their work.

Robbins and Judge (2013) define job involvement as the level at which a person identifies himself with work, participates actively in it, and considers performance important for self-esteem. Paullay, et al., (1994) define job involvement as the extent to which a person is cognitively busy, involved, and concerned with his current job. Kanungo (1982) defines job involvement as an individual commitment or someone's psychological identification with his work. Job involvement is how individuals see their work as a relationship with the work environment, the work itself and how their work and life mix. This definition implies that employees who are very involved in their work will see work "as an important part of their self-concept" (Lawler and Hall, 1970), and that work defines one's self-concept on a large scale (Kanungo, 1982).

Employee job involvement is estimated to have a significant impact on various important organizational outcomes. Regarding performance, Brown (1996) argues that employee work behavior must be categorized as a consequence of job involvement, and hypothesizes that job involvement influences employee motivation and effort which then determines performance.

Studies conducted by Hettiararchchi \& Jayarathna (2014) prove that there is a positive relationship between job involvement and in-role performance. In line with Hettiararchchi \& Jayarathna (2014), a study conducted by Chughtai (2008) reaffirms that job involvement is an important determinant of individual performance. Chughtai (2008) in his study of lecturers in Pakistan proved that lecturers with a high level of involvement in their work tended to produce higher performance.

\section{Effort}

Conceptually, effort is often considered the same as motivation For example, motivation is defined as a number of efforts devoted to work-related tasks (Campbell and Pritchard, 1976; Steers et al., 2004). But a more meaningful explanation then appears that distinguishes motivation from effort. Motivation is considered to represent the psychological state or tendency of individuals in relation to choices involving direction, intensity, and constancy of behavior. The effort represents strength, energy, or activity in which work is carried out.

Lloyd (2008) defines effort as a voluntary effort issued by employees that is above the minimum level of effort needed to maintain employment and is directed towards organizational goals. Effort is defined as the level of intensity of time and work commitments that individuals are dedicated to achieving performance (Brown \& Leigh, 1996). In the proposed model, effort mediates the relationship between job attitudes and job performance. Several studies have supported the relationship between effort and performance (eg, Blau, 1993; Brown \& Leigh, 1996; Gardner, Dunham, Cummings \& Pierce, 1989). Brown \& Peterson (1994) in his research proved that effort has a significant positive effect on performance.

\section{Kinerja Dosen}

Borman \& Motowidlo (1997) explained that performance refers to employee activities related to the main formal role of employees. Performance is defined as all behaviors needed in completing work responsibilities (Williams \& Anderson, 1991).

Performance is an important factor that influences organizational performance. In the context of education, the performance of lecturers has a strategic role and is the main factor that determines student performance and ultimately the performance of universities (Sukirno, 2011). Kingdon and Teal (2007) state that teachers are central actors in the learning process that takes place at school. Studying the factors that influence the performance of lecturers at higher education institutions from various settings is very useful not only to enrich and refine the theory, but also to develop recommendations in order to improve the quality of higher education institutions.

The study by Fah and Osman (2011) for example, in assessing the overall performance assessment of lecturers, they use two dimensions: effective and the best educators. Similarly Halim (2009) in measuring the performance of lecturers in universities that adopt an objective approach. Halim (2009) noted that the performance of lecturers at universities is often based on three main objectivity of their professional responsibilities (Tridharma of Higher Education), namely education and teaching assignments, research assignments, and community service assignments. From the description above, the lecturer performance referred to in this study is the work of the 
lecturer related to activities related to his main formal role as a lecturer. The activity in question is related to the implementation of the Tridharma of Higher Education.

\section{Psychological Empowerment $\rightarrow$ Effort}

The organization influences the effort of work through motivation, and effective motivation is achieved through handling individual needs and goals positively, namely by giving extrinsic or intrinsic rewards; which in turn affects effort in work (Evans, et al., 2002). Empowerment can be seen as a motivational process. Effects that can be explained by psychological theory such as the theory of self-efficacy. Self-efficacy as a motivation theory was developed by Bandura (1977) who proposed that people who have a perception of self-efficacy and higher selfesteem usually have higher standards and performance goals, show a more positive work attitude and issue effort that greater for completing challenging tasks.

There are not many studies that explore the relationship between psychological empowerment and effort of employees. Moreover, there have been no studies that analyze the influence of psychological empowerment on effort in the context of higher education. The study of Durrani, et al (2017) only tests some dimensions of psychological empowerment, namely meaning, competence and impact where the results have a significant positive relationship with effort, but the self-determination dimension is not related to effort.

H1. There will be a positive and significant relationship between psychological empowerment and effort

\section{Psychological Empowerment $\rightarrow$ In-role performance}

Empowerment is related to the freedom to act and have the opportunity to be responsible for the results of performance, the availability of necessary resources, compensation for expected mistakes, commitment and collaboration in the process of success of the employee itself and the success of others (Duvall, 1999). Organizational members who have flexibility and control in decision making tend to feel satisfied with life outside of work. Employees who believe in their ability to complete work-related tasks tend to have fewer doubts about themselves and their work, which increases in-role performance (Liden, et al., 2000; Stajkovic \& Luthans, 1998 )

Academics who have control over teaching and are active in decision-making processes related to curricular, instructional and organizational issues, generally consider themselves empowered (Short \& Johnson, 1994; Hawks, 1999). Academics in higher education need high autonomy (Moses, 2007). This autonomy arises from social contracts and in higher education, academics gain this autonomy through academic freedom, peer review, and joint governance. This autonomy also increases job satisfaction, effectiveness and performance (Phillips, et al. 2010). In addition, in-role performance can be improved when academics are given autonomy over how their work must be completed (Miller \& Monge, 1986).

H2. There will be appositive and significant relationship between psychological empowerment and in-role performance

\section{Job Involvement $\rightarrow$ Effort}

The concept of job involvement was first introduced by Lodahl and Kejner (1965), and received a lot of attention because it was in the field of organizational behavior and work psychology. Job involvement can be defined as the extent to which a person's performance influences his self-esteem (Lodahl and Kejner, 1965). With a higher level of job involvement, individuals will spend more time and effort on their work. As discussed earlier, Brown and Leigh (1996) found that job involvement is positively related to job performance through effort. In another study, Brown (1996) developed a theoretical framework related to antecedents, correlations and consequences of work involvement. From the study, Brown concluded that the relationship between job involvement and work behavior (such as performance, absenteeism, and turnover) was generally weak. Only one combination shows significant results, namely the relationship between work involvement and effort.

H3. There will be a positive and significant relationship between job involvement and effort

Job Involvement $\rightarrow$ In-role Performance

Employee job involvement is estimated to have a significant impact on various important organizational outcomes. Regarding in-role performance, Brown (1996) argues that employee work behavior must be categorized 
as a consequence of work involvement, and hypothesizes that work involvement affects employee motivation and effort which then determines performance.

A recent study conducted by Hettiararchchi and Jayarathna (2014) shows that there is a positive relationship between work involvement and in-role performance. In line with Hettiararchchi and Jayarathna (2014), a study conducted by Chughtai (2008) reaffirms that work involvement is an important determinant of individual performance. Chughtai (2008) in his study of lecturers in Pakistan proved that lecturers with a high level of involvement in their work tended to produce higher performance.

H4. There wil be a positive and significant relatiponship between job involvement and in-role performance

\section{Effort $\rightarrow$ In-role Performance}

Effort is defined as the level of intensity of time and work commitments that individuals are dedicated to achieving performance (Brown and Leigh, 1996). In the proposed model, effort mediates the relationship between work attitudes and job performance. Several studies have supported the relationship between effort and in-role performance (for example, Blau, 1993; Brown \& Leigh, 1996; Gardner, et al, 1989).

Lai and Chen (2012) conducted a study that focused on characteristics (self efficacy and effort) and how these variables affected performance (in-role performance, job satisfaction, and turnover intention). The results of data processing prove that 1) Self-efficacy has a positive effect on in-role performance; 2) self-efficacy has a positive impact on job satisfaction; and 3) effort relates to postal and in-role performance. Brown \& Peterson (1994) in his research proved that effort has a significant positive effect on employee performance.

H5. There will be a positive and significant relationship between effort and in-role performance

\section{Psychological Empowerment $\rightarrow$ Effort $\rightarrow$ In-role Performance}

The results of the Chiang \& Hsieh (2012) study show that when employees exert effort, give extra attention and effort beyond their job description, then at that time the human and capital resources used are most effective. Therefore, improving the psychological state and social environment of the entire organization can improve overall employee performance. In other words, if more behavior starts on its own, employee performance increases.

It is logical to expect that effort, initiative, concentration, and perseverance will increase when employees feel empowered (Conger \& Kanungo, 1988; Thomas \& Velthouse, 1990). In addition, previous studies have shown that the constructs related to effort have a positive relationship with psychological empowement, including in-role performance (Bartram and Casimir, 2007; Hechanova et al., 2006).

According to Janssen (2004), psychological empowement can be seen as a way to stimulate an individual's commitment to an organization, because this leads to a match between work roles and personal value systems; confidence in the individual's ability to work well, which in turn encourages him to exert more effort; broader participation in decision making; and performance contributions to form an organizational system with greater impact.

H6. Psychological empowerment will have a positive and significant effect on in-role performance through effort

Job Involvement $\rightarrow$ Effort $\rightarrow$ In-role Performance

Generally it is believed that the influence of positive job involvement on employee motivation and effort leads to higher in-role performance (Brown, 1996). Some previous studies indicate support for these claims. Research from Brown and Leigh (1996) for example, in their study found that job involvement has a direct and indirect effect on performance through effort. More specifically, they found that a simple but statistically significant relationship between job involvement and performance became insignificant when effort was included in the model where this indicated a mediating effect of effort on the relationship between job involvement and in-role performance. Rabinowitz and Hall (1977) emphasize that job involvement increases as a result of an increase in satisfaction in work, and in turn, the more involved a person is, the greater the effort that he will spend in doing his work. This shows the mediating effect of the effort on the relationship. In addition, employees who psychologically 
identify with work are more likely to show hard effort at work, and this extra effort increases the likelihood that they will perform well and get rewards (Kanungo, 1982; Lawler \& Hall, 1970).

H7. Job involvement will have a positive and significant effect on in-role performance through effort

\section{Methodology:- \\ Sample}

Proportionate stratified random sampling was used in collecting data from 307 lecturers who already possessed professional lecturer certificates from 20 private universities in South Sulawesi.

\section{Data}

Data were collected using questionnaires distributed to 425 professional private lecturers by handing it personally, via email, and google form. There were 342 returned questionnaires that filled properly, but the questionnaires processed in this study amounted to 307 considering that the amount was in accordance with the minimum number of samples required in this study. Data were processed using the Partial Least Squares Structural Equation Modeling (PLS-SEM). Both primary and secondary data have been used for the study. Thus, a selected sample of private lecturers is the primary source of data. Secondary data were collected from the various reports, magazines, journals and official files of the organization.

\section{Measures}

1. Instruments containing closed-ended questions have been used as a tool to extract information keeping in mind the objective and design of study.

2. Psychological empowerment

3. Scale to measure psychological empowerment used an adaptation of Short and Rinehart's (1992) scale for educational context. This scale was built based on six dimensions: professional growth, impact, status, selfefficacy, autonomy, and decision making.

4. Job involvement

5. For measuring job involvement, a 15-item scale based on Yoshimura's (1997) multi-dimensional concept has been used. This concept consists of three dimensions: emotional job involvement, cognitive job involvement, and behavioral job involvement.

6. Effort

7. Effort was measured using a 9 item-scale scale that adopted from Lloyd's (2008) Discretionary Effort Scale.

\section{Results:-}

Outer Model

Convergent validity is tested by using the value of outer loading or loading factor. Indicators are stated to meet convergent validity if the value of outer loading> 0.7. According to Chin (1998) the value of outer loading between $0.5-0.6$ is considered sufficient to meet the convergent validity requirements. In the first test, there were two items that were below 0.5 , namely X2.3 $(0.223)$ and Y2.6 (0.255) so that the two indicators were not included in the second stage of test. Results of outer loading from the second stage test results can be seen in Table 1 . 
Tabel 1. Outer Loading

\begin{tabular}{|c|c|c|c|c|c|}
\hline PE (X1) & Loading Factor & p-value & Effort (Y1) & Loading Factor & p-value \\
\hline$\times 1.1$ & 0.576 & $<0.001$ & Y1.1 & 0.617 & $<0.001$ \\
\hline$\times 1.2$ & 0.533 & $<0.001$ & Y1.2 & 0.692 & $<0.001$ \\
\hline$\times 1.3$ & 0.639 & $<0.001$ & Y1.3 & 0.583 & $<0.001$ \\
\hline$\times 1.4$ & 0.614 & $<0.001$ & Y1.4 & 0.588 & $<0.001$ \\
\hline$\times 1.5$ & 0.503 & $<0.001$ & Y1.5 & 0.604 & $<0.001$ \\
\hline$\times 1.6$ & 0.510 & $<0.001$ & Y1.6 & 0.573 & $<0.001$ \\
\hline$\times 1.7$ & 0.578 & $<0.001$ & Y1.7 & 0.694 & $<0.001$ \\
\hline$\times 1.8$ & 0.615 & $<0.001$ & Y1.8 & 0.709 & $<0.001$ \\
\hline$\times 1.9$ & 0.605 & $<0.001$ & Y1.9 & 0.703 & $<0.001$ \\
\hline$\times 1.10$ & 0.629 & $<0.001$ & $\operatorname{IRP}(\mathbf{Z} \mathbf{)})$ & Loading Factor & p-value \\
\hline$\times 1.11$ & 0.515 & $<0.001$ & Y2.1 & 0.577 & $<0.001$ \\
\hline$\times 1.12$ & 0.561 & $<0.001$ & Y2.2 & 0.634 & $<0.001$ \\
\hline$\times 1.13$ & 0.609 & $<0.001$ & Y2.3 & 0.547 & $<0.001$ \\
\hline$\times 1.14$ & 0.534 & $<0.001$ & Y2.4 & 0.646 & $<0.001$ \\
\hline$\times 1.15$ & 0.535 & $<0.001$ & Y2.5 & 0.663 & $<0.001$ \\
\hline J (x) & Loading Factor & p-value & Y2.7 & 0.638 & $<0.001$ \\
\hline$\times 2.1$ & 0.681 & $<0.001$ & Y2.8 & 0.608 & $<0.001$ \\
\hline$\times 2.2$ & 0.739 & $<0.001$ & Y2.9 & 0.648 & $<0.001$ \\
\hline$\times 2.4$ & 0.732 & $<0.001$ & & & \\
\hline$\times 2.5$ & 0.691 & $<0.001$ & & & \\
\hline$\times 2.6$ & 0.658 & $<0.001$ & & & \\
\hline$\times 2.7$ & 0.681 & $<0.001$ & & & \\
\hline$\times 2.8$ & 0.608 & $<0.001$ & & & \\
\hline$\times 2.9$ & 0.578 & $<0.001$ & & & \\
\hline
\end{tabular}

As for discriminant validity, an indicator is stated to fulfill discriminant validity if the value of the cross loading indicator in the variable is the biggest compared to the other variables. Based on data processing, each indicator in the research variable has the largest cross loading value compared to the cross loading value in other variables. Therefore it can be stated that the indicators used in this study have good discriminant validity in compiling their respective variables (see table 2).

Tabel 2:-Cross Loading

\begin{tabular}{|l|c|c|c|c|}
\hline & PE (X1) & JI (X2) & Effort (Y1) & IRP(Y2) \\
\hline X1.1 & 0.576 & 0.306 & 0.377 & 0.295 \\
\hline $\mathrm{X} 1.10$ & 0.629 & 0.479 & 0.304 & 0.359 \\
\hline $\mathrm{X} 11$ & 0.515 & 0.313 & 0.364 & 0.297 \\
\hline $\mathrm{X} 1.12$ & 0.561 & 0.327 & 0.296 & 0.23 \\
\hline $\mathrm{X} 1.13$ & 0.609 & 0.476 & 0.309 & 0.283 \\
\hline $\mathrm{X} 1.14$ & 0.534 & 0.309 & 0.262 & 0.162 \\
\hline $\mathrm{X} 1.15$ & 0.535 & 0.316 & 0.215 & 0.218 \\
\hline $\mathrm{X} 1.3$ & 0.533 & 0.237 & 0.391 & 0.326 \\
\hline $\mathrm{X} 1.4$ & 0.639 & 0.338 & 0.349 & 0.276 \\
\hline $\mathrm{X} 1.5$ & 0.614 & 0.351 & 0.311 & 0.267 \\
\hline $\mathrm{X} 1.6$ & 0.503 & 0.348 & 0.293 & 0.276 \\
\hline $\mathrm{X} 1.7$ & 0.51 & 0.435 & 0.32 & 0.287 \\
\hline $\mathrm{X} 1.8$ & 0.578 & 0.443 & 0.332 & 0.296 \\
\hline $\mathrm{X} 1.9$ & 0.615 & 0.366 & 0.311 & 0.278 \\
\hline $\mathrm{X} 2.1$ & 0.605 & 0.499 & 0.38 & 0.36 \\
\hline $\mathrm{X} 2.2$ & 0.473 & 0.681 & 0.417 & 0.363 \\
\hline $\mathrm{X} 2.4$ & 0.514 & 0.739 & 0.448 & 0.357 \\
\hline $\mathrm{X} 2.5$ & 0.476 & 0.732 & 0.351 & 0.33 \\
\hline $\mathrm{X} 2.6$ & 0.449 & 0.691 & 0.395 & 0.336 \\
\hline $\mathrm{X} 2.7$ & 0.347 & 0.658 & 0.378 & 0.353 \\
\hline $\mathrm{X} 2.8$ & 0.391 & 0.681 & 0.536 & 0.36 \\
\hline $\mathrm{X} 2.9$ & 0.434 & 0.608 & 0.347 & 0.268 \\
\hline Y1.1 & 0.397 & 0.578 & 0.617 & 0.313 \\
\hline Y1.2 & 0.208 & 0.271 & 0.692 & 0.303 \\
\hline Y1.3 & 0.292 & 0.311 & 0.583 & 0.343 \\
\hline Y1.4 & 0.263 & 0.384 & 0.588 & 0.304 \\
\hline Y1.5 & 0.329 & 0.454 & 0.604 & 0.309 \\
\hline Y1.6 & 0.417 & 0.392 & 0.573 & 0.301 \\
\hline
\end{tabular}




\begin{tabular}{|c|c|c|c|c|}
\hline Y1.7 & 0.413 & 0.423 & 0.694 & 0.422 \\
\hline Y1.8 & 0.459 & 0.432 & 0.709 & 0.38 \\
\hline Y1.9 & 0.425 & 0.422 & 0.703 & 0.318 \\
\hline Y2.1 & 0.296 & 0.345 & 0.245 & 0.577 \\
\hline Y2.2 & 0.356 & 0.343 & 0.313 & 0.634 \\
\hline Y2.3 & 0.327 & 0.341 & 0.315 & 0.547 \\
\hline Y2.4 & 0.298 & 0.332 & 0.33 & 0.646 \\
\hline Y2.5 & 0.264 & 0.303 & 0.382 & 0.663 \\
\hline Y2.7 & 0.264 & 0.289 & 0.337 & 0.638 \\
\hline Y2.8 & 0.29 & 0.224 & 0.255 & 0.608 \\
\hline Y2.9 & 0.271 & 0.339 & 0.392 & 0.648 \\
\hline
\end{tabular}

In addition to observing the value of cross loading, discriminant validity can also be revealed through other methods, namely by looking at the value of Average Varied Extracted (AVE) for each indicator, the value must be $>0.5$ for good models (Fornell and Larcker, 1981).

Table 3:-Average Variant Extracted (AVE)

\begin{tabular}{|l|c|}
\hline \multicolumn{1}{|c|}{ Variabel } & AVE \\
\hline Psychological Empowerment (X1) & 0.527 \\
\hline Keterlibatan Kerja (X2) & 0.553 \\
\hline Effort (Y1) & 0.513 \\
\hline In-role Performance (Y2) & 0.586 \\
\hline
\end{tabular}

Based on the data presented in the table 3 above, it is known that the value of AVE psychological empowerment, job involvement, effort and in-role performance $>0.5$. Thus it can be stated that each variable has good discriminant validity.

Composite reliability is used to test the reliability of indicators on a variable. A variable can be declared to meet composite reliability if it has a composite reliability value $>0.6$ (Ghozali, 2014). Reliability tests with composite reability can be strengthened by using the cronbach's alpha value. A variable can be declared reliable or meets cronbach's alpha if it has a cronbach's alpha value $>0.7$. The following is composite reliability and cronbach's alpha from each variable:

Table 4:-Composite Reliability and Cronbach's Alpha

\begin{tabular}{|l|c|c|}
\hline & Composite Reliability & Cronbach's Alpha \\
\hline Effort (Y1) & 0.863 & 0.821 \\
\hline In-Role Performance (Y2) & 0.834 & 0.772 \\
\hline Keterlibatan Kerja (X2) & 0.868 & 0.826 \\
\hline Psychological Empowerment (X1) & 0.879 & 0.853 \\
\hline
\end{tabular}

Based on the data in table 4 above, it can be seen that the composite reliability value of all research variables $>0.6$. These results indicate that each variable has met composite realibility. This is supported by the value of Cronbach's alpha from each study variable $>0.7$. Thus these results can show that each research variable has met the requirements of the Cronbach's alpha value, so it can be concluded that the overall variable has a high level of reliability.

\section{Inner Model}

The path coefficient is used to show how strong the effect or influence of the independent variable is on the dependent variable. Based on the results of the bootstrapping test (figure1), it can be explained that the greatest path coefficient value is indicated by the effect of job involvement on effort amounting to 7.477. Then the second biggest influence is the influence of psychological empowerment on effort amounting to 5,279. Followed by the influence of 
effort on in-role performance of 4,398. Then the effect of job involvement on in-role performance is 3.006. The next path coefficient value is the influence of psychological empowerment on in-role performance as big as 2.815 .

Based on the description of the results, it shows that all variables in this model have a path coefficient with positive numbers. This shows that if the path coefficient value is greater on an independent variable on the dependent variable, the influence of the independent variables on the dependent variable will be stronger.

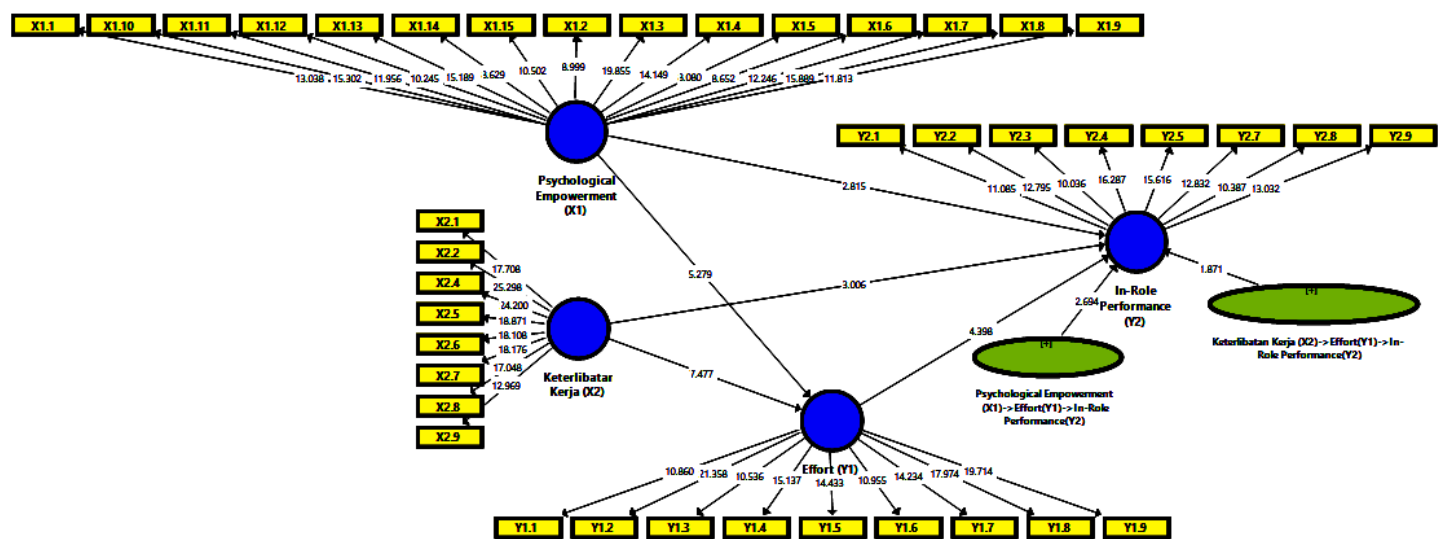

Figure 1:-Bootstrapping Test

The next step is to look at the value of $\mathrm{R}^{2}$.

Table 5:- $\mathrm{R}^{2}$ Value

\begin{tabular}{|l|c|}
\hline \multicolumn{1}{|c|}{ Variabel } & R Square \\
\hline Effort (Y1) & 0.423 \\
\hline In-role Performance (Y2) & 0.346 \\
\hline
\end{tabular}

Based on table 5 above, it can be interpreted that the psychological empowerment variable (X1) and job involvement (X2) together can explain the effort (Y1) of $0.423(42.3 \%)$, while the other variables are not explained in the model by $0.577(57,7 \%)$. Then the in-role performance (Y2) variable can be explained together by psychological empowerment (X1) and job involvement (X2) and effort (Y1) as of 0.346 (34.6\%). The other variables not explained in the model are $0.654(65.4 \%)$.

\section{Hypotheses Testing}

Testing hypotheses is basically to test theories based on empirical evidence in the field. From the results of data processing, it can be seen the magnitude of the relationship of exogenous variables to endogenous variables, both direct and indirect relationships and their level of significance.

Table 6:-Direct Effect Test Results

\begin{tabular}{|c|c|c|c|c|}
\hline Variable & Prediction & Direct Effecf & p-Value & Sig/No.Sig \\
\hline $\mathrm{X} 1$-> Y1 & + & 0.284 & 0.000 & Significant \\
\hline $\mathrm{X} 1$-> Y2 & + & 0.191 & 0.005 & Significant \\
\hline $\mathrm{X} 2$-> Y1 & + & 0.429 & 0.000 & Significant \\
\hline $\mathrm{X} 2$-> Y2 & + & 0.221 & 0.003 & Significant \\
\hline $\mathrm{Y} 1$-> Y2 & + & 0.287 & 0.000 & Significant \\
\hline
\end{tabular}

Based on table 6 , the results of this test can be explained as follows:

1. Psychological empowerment has a direct and significant effect on the effort of lecturers in South Sulawesi with a path coefficient of 0.284 with p-value of 0.000 so that hypothesis 1 is accepted.

2. Psychological empowerment has a direct and significant effect on the in-role performance of lecturers in South Sulawesi with path coefficient values 0.191 with $\mathrm{p}$ - value 0.003 so that hypothesis 2 is accepted.

3. Job involvement has a direct and significant effect on the effort of lecturers in South Sulawesi with path coefficient value 0.429 with p-value 0.000 so that hypothesis 3 is accepted. 
4. Job involvement has a direct and significant effect on private university lecturers ' in-role performances in South Sulawesi with path coefficient values 0.221 with p-value 0.003 so hypothesis 4 is accepted.

5. Effort has a positive and significant effect on lecturers' in-role performance with path coefficient value 0.287 with p-value 0.000 so that hypothesis 5 is accepted.

Table 7:-Indirect Effect Test Results

\begin{tabular}{|c|c|c|c|c|}
\hline Variable & Prediction & Indirect Effect & P-Value & Sig/No.Sig \\
\hline $\mathrm{X}_{1} \rightarrow \mathrm{Y}_{2}$ through $\mathrm{Y}_{1}$ & + & 0.183 & 0.007 & Significant \\
\hline $\mathrm{X}_{2} \rightarrow \mathrm{Y}_{2}$ through $\mathrm{Y}_{1}$ & + & 0.126 & 0.062 & Insignificant \\
\hline
\end{tabular}

\section{Discussion:-}

\section{Summary of results}

Referring to the results of this study, psychological empowerment empirically proved to have a significant effect on effort. This means that the greater the perceptions and beliefs of the lecturers that they have the ability to do a good job, have control and autonomy while working, then the greater effort that they will exert in doing their work. This finding is supported by the results of Durrani, et al (2017), that psychological empowerment has a positive effect on effort.

Based on the results of the data analyzed, psychological empowerment proved to have a positive and significant effect on the in-role performance of private university lecturers in South Sulawesi. This shows that the greater psychological empowerment perceived by lecturers, the better/higher their in-role performance.

Psychological empowerment in this study is defined as the perceptions and beliefs of the lecturer that he has the ability to do a good job, have control and autonomy at work and in influencing his work. Psychological empowerment was measured based on six important dimensions in the educational context introduced by Short and Rinehart (1992 ), namely decision making; professional growth; status; self-efficacy; autonomy; and impact.

Empirical findings reflects that private university lecturers in South Sulawesi have a responsibility in monitoring programs and flexibility in arranging their schedules related to the Tri Dharma activities. According to Short and Johnson (1994), campuses that provide important roles to lecturers in decision making are key elements in empowerment where they get the opportunity to increase control over their work environment, which in turn will improve performance. This is in line with the results of research conducted by Gruber and Trickett (1987) in the context of education where they identified the importance of control over decision making in an effort to increase empowerment in school organizations. Liden, et al.,'s findings (2000) confirm this by proving that employees who have control over their work-related decisions have higher in-role performance than those without control. Therefore, it is proven that the performance of lecturers can be improved if given autonomy in making decisions related to their work.

Empirical findings also show that in general, lecturers consider the campus to provide a great opportunity for them to continue to develop professionally, either by continuing their studies to a higher level or to take part in trainings that can improve the ability of lecturers. This result is in line with the results of a study from Usop, et al (2013) which proves that educators who show high in-role performance are those who are satisfied with the opportunities offered to them to develop professionally. Studies from Rinehart and Short (1993) also suggest that performance can be improved by creating an environment that supports empowerment, one of which is professional development. If educators are expected to provide students with the best educational environment for learning, then educators must be given the best environment to succeed and grow professionally (Keith and Girling, 1991) .

Empirical evidence shows that the majority of respondents view their status as lecturers as being valued by others and they have positive beliefs about their profession as lecturers. This condition according to Lindsay, et al (2002) is very ideal and important in order to improve their performance. The results of the study of Lindsay, et al (2002) are consistent with the findings of this study, where their research shows that appreciation and support for academics is a feasible method for campus managers to improve the performance of lecturers in an effective and efficient way.

The results of this study showed that the self-efficacy indicator had the highest average compared to other indicators. This indicates that the self-efficacy indicator is an important indicator on the psychological 
empowerment variable, and that the majority of university lecturers in South Sulawesi have a high level of selfefficacy. The higher the individual's perception of self-efficacy, the more committed to completing the tasks given so that their performance is even higher (Goodale, et al, 1997; Taylor, 2013). The results of this study are in line with the Conger and Kanungo studies, (1988); and Chebat and Kollias, (2000) who revealed that self-efficacy is the most relevant and important empowerment element.

Autonomy is the following indicator of psychological empowerment. In this study, the intended autonomy is the belief of the lecturer that they can control certain aspects of their work life. This control can be in the form of control over schedules, curriculum, material and research. The results of this study indicate that the majority of private lecturers in South Sulawesi have control over several important aspects of their work. Deci, et al (1989) explains that those who have autonomy for their work will make more rational choices and can better manage their actions. This result is in line with the study of Spreitzer et al. (1997) who also found that the autonomy dimension of psychological empowerment is positively related to job satisfaction and in-role performance, and that autonomy is a psychological need that is a key component of intrinsic motivation.

The final indicator of the variable psychological empowerment is impact, which refers to the lecturers' belief that they have an impact and influence on their workplace. This is in line with the opinion of Shapira-Lishchinsky and Tsemach (2014) that in the context of education, impact is the ability of the teacher to feel the possibility of influencing an event in the organization. When impact is on the lecturer, they will feel that they are able to produce better performance and have significant influence in their respective institutions. Therefore, the campus must provide opportunities for its lecturers to provide ideas and suggestions regarding the implementation of teaching and learning activities and other tasks related to the tri dharma of higher education. This according to Choong, et al (2011) will have a positive impact on the results of their work. In addition, academics with empowered environments are able to carry out heavy tasks, build initiatives, and be able to work in teams as well as individually, which in turn increases their performance levels (Eisenberger, et al, 1990 and Kraimer, et al, 1999).

Based on the results of statistical tests, job involvement is proven to have a positive and significant direct influence on effort. The positive and significant influence explained that job engagement practices are crucial and important factors to be considered by the university because it is related to the increasing lecturers 'effort. This finding is also in line with previous studies conducted by Gechman and Wiener (1975) and Wiener and Vardi (1980) who found it important to treat the concept of job involvement as a different work attitude because job involvement has important behavioral correlations that are characterized by personal commitment and investment in the form of effort towards work.

Another important finding of this study is that job involvement has a positive and significant effect on in-role performance of private university lecturers in South Sulawesi. This means that the higher the job involvement perceived by the lecturer, the higher the level of in-role performance produced. The positive and significant influence reflects that job involvement practices which include emotional job involvement, cognitive job involvement, and behavioral involvement are important factors that must be considered by the foundation and campus managers related to efforts to improve lecturers' in-role performance.

The results of this study reinforce the results of Rotenberry and Moberg (2007) who revealed that the construct of job involvement predicts in-role performance well if measured correctly. Their study supports the argument from Diefendorff, et al (2002) that work involvement will have a significant impact on in-role performance if using a measuring device that is not contaminated with foreign constructs (eg intrinsic motivation). A study conducted by Chughtai (2008) on 195 lecturers at 53 universities in Pakistan also supported the results of this study. This study confirms that job involvement is an important factor that has the potential to determine individual performance. This result is in line with a recent study conducted by Odero and Makori (2018). Their study of parttime lecturers at universities in Kenya proved that job involvement was positively and significantly correlated with lecturer in-role performance. Thus this study found that job involvement has a large influence on the performance of lecturers.

Also the finding of this study is that effort has a positive and significant direct effect on in-role performance which supports the hypothesis. The positive and significant influence explains that effort is a crucial factor that important to strive for by the university because it is related to increasing the in-role performance of lecturer. This result is in 
line with the results of previous studies which proved the relationship between effort and in-role performance (eg, Blau, 1993; Brown and Leigh, 1996; Christen, et al, 2006).

Empirical psychological empowerment variables proved to have a positive and significant effect on in-role performance through effort. This means that psychological empowerment and effort are good predictors of in-role performance. Efforts play an important role in the transformation of psychological empowerment towards performance. Lecturers who feel that their work is meaningful, have the opportunity to participate in campus decision-making, have confidence in competencies related to their work, and have an impact on others through the success of completing their teaching and research assignments, will exert extra effort that ultimately results in performance. According to Janssen (2004), psychological empowement can be seen as a way to stimulate an individual's commitment to an organization, because this leads to a match between work roles and personal value systems; confidence in the individual's ability to work well, which in turn encourages him to exert effort;broader participation in decision making; and performance contributions to form an organizational system with greater impact.

On the contrary, job involvement does not prove to have indirect and significant effect on in-role performance through effort. This indicates that effort does not mediate the relationship between job involvement and in-role performance. This condition can occur due to job involvement is a strong driver to motivate employees to work and at the same time is also a behavior that can be directed to desired goals (Diefendorff et al., 2002; Hackman \& Lawler, 1971; Kahn, 1990; Lawler \& Hall, 1970 ). Performance improvement itself is very dependent on the motivation of each lecturer in carrying out his work. The existence of positive job involvement psychologically motivates lecturers to produce optimal performance and produce behaviors that are beneficial to their careers. Effort itself tends to have more influence on how hard a person performs a task (Porter and Lawler, 1968) in terms of quantity and not quality. Efforts that are more needed in the context of higher education are those related to working smart and related to lecturer innovation, creativity, adaptability and flexibility of lecturers (Brown, 1996). Therefore, the relationship between job involvement and in-role performance does not seem to require effort as a mediation to strengthen each other.

This result is not consistent with the results of studies conducted by Brown and Leigh (1996). The findings of Brown and Leigh's study clearly show that effort mediates the relationship between work involvement and employee performance. One of the alleged causes of differences in the results is that there were differences in the characteristics of research objects, where the sample from Brown and Leigh's study consists of salespeople so that the findings of the study cannot be generalized outside of the profession as stated by Brown and Leigh themselves (1996).

\section{Implications}

The results of this study provide a theoretical contribution to the development of HR management field, especially in the area of job attitudes namely psychological empowerment, job involvement, and effort and how they relate to inrole performance.

1. This research contributes to the development of the concept of self-efficacy proposed by Bandura (1977), especially in relation to employee effort. Self-efficacy as a motivation theory developed by Bandura proposes that those who have high perceptions of self-efficacy and self-esteem tend to have higher standards and performance goals, show more positive work attitudes and spend more effort on completing challenging tasks. High self-efficacy (as one of the dimensions of psychological empowerment) will produce the willingness to exert more effort and perseverance in facing obstacles. This concept is proven empirically where the greater the perceptions and beliefs of the lecturers that they have the ability to do a good job, to have control and autonomy while working, the greater the effort that the lecturers make in doing their work.

2. This research also contributes to effort construction related to its relation to individual performance. Previous studies put effort as part of in-role performance and defined it broadly as efforts, skills, and produce outcomes that are important for both employees and companies (for example, Behrman and Perreault, 1984; Lusch and Serpkenci, 1990; and Lloyd, 2008) On the contrary, based on the findings of this study, it is argued that it is important to define effort as something different from in-role performance. From the perspective of a lecturer, effort and performance are not the same. Effort is input to work, while in-role performance is the output of effort. 
This research provides a practical contribution to higher education, especially at private universities in South Sulawesi, which include:

1. The results of this study prove that effort plays an important role in improving the performance of lecturers. However, with the rapid development of science and technology, this requires lecturers to be able to work effectively and efficiently. It is important for lecturers to consider channeling energy effort to work smart. Efforts that are more needed in the context of higher education are those that are related to working smart, which are related to lecturer innovation, creativity, adaptability and flexibility of lecturers.

2. The implementation of appropriate HRM practices for university workforce will not only improve lecturer performance, but also have a positive impact on university performance because lecturers have a crucial role in improving important fields, such as research quality, university academic image, program quality, graduate quality, contribution to society, and in preparing experts in the future.

\section{Limitations and areas for future research}

The researchers have tried their best to do good research in order to develop a research model, but in its implementation can not be separated from shortcomings and limitations, including:

1. Research variables were measured based on the perceptions of respondents who were also subjects of the study. This can cause a bias response in obtaining data on each variable. Examination of respondents in an excessive manner and how to respond to a minimum will have an impact on findings and results that are not in line with expectations. These shortcomings can be minimized by further researchers by combining the self-rated evaluation method with the rating supervisor especially on performance variables to obtain more accurate data.

2. This study only used data in one time period or cross section data so that the results were not able to explain the dynamics of changes in conditions or relationships of respondents observed in different time periods. Future research using time-series can be considered to eliminate deficiencies as described above.

3. This study combines the results of descriptive statistics and inferential statistics, but the results of this study are limited to generalizations on private universities in South Sulawesi alone considering the scope of the sample in this study is limited only in South Sulawesi Province. This limitation can be overcome by the next researcher by accommodating a wider population and considering other variables that determine lecturer performance such as organizational support, competence, locus of control, leadership style and other variables.

\section{References:-}

1. Ahadi, S., \& Suandi, T. (2014). Structural Empowerment and Organizational Commitment: The Mediating Role of Psychological Empowerment in Malaysian Research Universities. Journal of Asian development studies, 3(1).

2. Bandura, A. (1977). Social Learning Theory. Englewood Cliffs, NJ: Prentice-Hall

3. Bartram, T., \& Casimir, G. (2007). The relationship between leadership and follower in-role performance and satisfaction with the leader: The mediating effects of empowerment and trust in the leader. Leadership \& Organization Development Journal, 28(1): 4-19.

4. Behrman, D.N., \& Perreault, W.D. (1984), "A Role Stress Model of the Performance and Satisfaction of Industrial Salespersons," Journal of Marketing, 48 (Fall), 9-21.

5. Blau, G. J. (1993) Operationalizing Direction \& Level of Effort \& Testing Their Relationships to Individual Job Performance. Organizational Behavior \& Human Decision Processes, 55, 152-170.

6. Borman, W.C., \& Motowidlo, S.J (1997) Task performance \& contextual performance: The meaning for personnel selection research. Human Performance, 10, 99-109.

7. Brown, S. P (1996) A Meta-analysis \& Review of Organizational Research on Job Involvement. Psychological Bulletin, 120 (2): 235-255.

8. Brown, S. P., \& Leigh, T. W (1996) A New Look at Psychological Climate \& Its Relationship to Job Involvement, Effort, \& Performance. Journal of Applied Psychology, 81 (4): 358-368.

9. Brown, S. P., \& Peterson, R.A (1994) The effect of effort on sales performance \& job satisfaction, Journal of Marketing, 58 (2): 70-80.

10. Campbell, J.P. \& Pritchard, R. (1976) and book of 1976), "Motivation Theory in Industrial and Organizational Psychology",in Hand-book of Industrial and Organizational Psychology, Marvin Dunnette, ed. Chicago: Rand-McNally, 63-130.

11. Chebat, J. \& Kollias P. (2000). The Impact of Empowerment on Customer Contact Employees' Roles in Service Organizations, Journal of Service Research, 3 (1): 66-81. 
12. Chin, W. W. (1998). The partial least squares approach for structural equation modeling. In G. A. Marcoulides (Ed.), Methodology for business and management. Modern methods for business research (pp. 295-336). Mahwah, NJ, US: Lawrence Erlbaum Associates Publishers.

13. Chiang, C.-F., \& Hsieh, T.-S. (2012). The impacts of perceived organizational support and psychological empowerment on job performance: The mediating effects of organizational citizenship behavior. International Journal of Hospitality Management, 31(1): 180-190.

14. Choong, Y.O., Wong, K.L., \& Lau, T.C. (2011) Psychological empowerment and organizational commitment in the Malaysian private higher education institutions: a review and research agenda. Academic Research International. 1 (3): 236-245.

15. Christen, M., Iyer, G., \& Soberman, D (2006) Job Satisfaction, Job Performance, \& Effort: A Reexamination Using Agency Theory. Journal of Marketing, 70 (1): 137-150.

16. Chughtai, A. A (2008) Impact of Job Involvement on In-Role Job Performance \& Organizational Citizenship Behaviour, Journal of Behavioral \& Applied Management, 9 (2): 169-183.

17. Conger, J. A., \& Kanungo, R. N. (1988). The empowerment process: integration theory \& practice. Academy of Management Review. 13(3): 471-482.

18. Deci, E., Connell, J. \& Ryan, R. (1989). Self-determination in a work organization. Journal of Applied Psychology, 74: 580-590.

19. Dewettinck, K., Buyens, D., \& Singh, J. (2004). Psychological Empowerment in the Workplace: Reviewing the Empowerment Effects on Critical Work Outcomes. Vlerick Leuven Gent Management School Working Paper.

20. Dhani, A. (2017) Jumlah Doktor di Indonesia Tak Sebanding Jumlah Penduduknya, (Online), (https://tirto.id/jumlah-doktor-di-indonesia-tak-seb\&ing-jumlah-penduduknya-ckK9, diakses 26 Mei 2017).

21. Diefendorff, J. M., Brown, D. J., Kamin, A. M., \& Lord, R. G (2002) Examining the Roles of Job Involvement \& Work Centrality in Predicting Organizational Citizenship Behaviors \& Job Performance. Journal of Organizational Behavior, 23, 93-108.

22. Durrani, D. K., Xiangyang, L., \& Dilawar, S. M. (2017). Psychological Empowerment and Work Effort. Proceedings of the 9th International Conference on Information Management and Engineering - ICIME 2017

23. Duvall, C. K. (1999). Developing individual freedom to act: Empowerment in the knowledge organization. Participation \& Empowerment: an international journal. 7(8): 204-212.

24. Echiejile, I. (1994). Empowering disadvantaged employees. Empowerment in Organizations, 2(1): 31-37.

25. Eisenberger, R., Fasolo, P., \& Davis-LaMastro, V. (1990). Perceived organizational support and employee diligence, commitment, and innovation. Journal of Applied Psychology, 75, 51-59.

26. Evans, K., Hodkinson, P. and Unwin, L. (2002), Working to Learn: Transforming Learning in the Workplace, Kogan Page, London.

27. Fah, B.C.Y. \& Osman, S. (2011) A case study of student evaluation of teaching in university, International Education Studies, 4 (1): 44-50.

28. Fornell, C., \& Larcker, D. F. (1981). Evaluating Structural Equation Models with Unobservable Variables and Measurement Error. Journal of Marketing Research (18:1), pp. 39-50.

29. Gardner, D. G., Dunham, R. B., Cummings, L. L., \& Pierce, J. L. (1989) Focus of Attention at Work: Construct Definition \& Empirical Validation. Journal of Occupational Psychology, 62, 61-77.

30. Gechman, A. S., \& Wiener, Y. (1975) Job involvement and satisfaction as related to mental health and personal time devoted to work. Journal of Applied Psychology, 60, 521 - 523.

31. Ghozali, I. (2014) Structural Equation Modeling Metode Alternatif dengan Partial Least Squares (PLS). Semarang: Universitas Dipenegoro Semarang.

32. Goodale, J. C., Koerner, M., \& Roney, J. (1997). Analyzing the impact of service provider empowerment on perceptions of service quality inside an organization. Journal of Quality Management, 2(2): 191-215.

33. Gruber, J., \& Trickett, E. J. (1987). Can we empower others? The paradox of empowerment in a alternative public high school. American Journal of Community Psychology, 15, 353-372.

34. Hackman, R. R., \& Lawler, E.E III. (1971) Employee Reactions to Job Characteristics. Journal of Applied Psychology, 55 (3): 259-286.

35. Halim, Y.A. (2009) Development \& validation of an instrument to access the lecturers' performance in the education \& teaching duties, Jurnal Pendidikan Malaysia, 34 (2): 33-47.

36. Hawks, J. (1999). Organizational culture and faculty use of empowering teaching behaviors in selected schools of nursing. Nursing Outlook. 47: 67-72.

37. Hechanova, M. R. M., Alampay, R. B. A., \& Franco, E. P. (2006). Psychological empowerment, job satisfaction and performance among Filipino service workers. Asian Journal of Social Psychology, 9, 72-78. 
38. Hettiararchchi, H.A.H., \& Jayarathna, S.M.D.Y. (2014) The effect of Employee Work Related Attitudes on Employee Job Performance: A Study of Tertiary \& Vocational Education Sector in Sri Lanka. Journal of Business \& Management, 16 (4): 74-83.

39. Janssen, O. (2004). "The barrier effect of conflict with superior in the relationship between employee empowerment and organizational commitment." Work \& Stress, 18(1): 56-65.

40. Kanungo, R.N., (1982) Measurement of Job \& Work Involvement. Journal of Applied Psychology, 67 (3): 341 349.

41. Keith, S., \& Girling, R. H. (1991). In education, management, and participation: New directions in educational administration (pp. 214-250). Boston: Allyn and Bacon.

42. Kingdon, G. \& Teal, F. (2007) Does performance related pay for teachers improve student performance? Some evidence from India, Economics of Education Review, 26, 473-486

43. Kraimer, M. L., Seibert, S. E., \& Liden, R. C. (1999). Psychological empowerment as multi-dimensional construct: a test of construct validity. Journal of Educational and Psychology Measurement, 59 (1): 127-142

44. Lai, M.C., \& Chen, Y.C (2012) Self-Efficacy, Effort, Job Performance, Job Satisfaction, \& Turnover Intention: The Effect of Personal Characteristics on Organization Performance. International Journal of Innovation, Management \& Technology, 3 (4): 387-391.

45. Lawler, E.E. (1986). High involvement management: participative strategies fo rimproving organizational performance. San Francisco: Jossey-Bass.

46. Lawler, E.E. and D.T. Hall, 1970. Relationship of job characteristics to job involvement, satisfaction and intrinsic motivation. Journal of Applied Psychology, 54(4): 305-312.

47. Liden, R. C., Wayne, S. J., \& Sparrowe, R. T. (2000). An Examination of the Mediating Role of Psychological Emprovement on the Relations between the Job, Interpersonal Relationships, \& Work Outcomes. Journal of Applied Psychology, 85 (3): 407-416.

48. Lindsay, S. E., Sugai, G., \& De Pry, R. L. (2002). Perceptions of work performance recognition among educators. Journal of Behavioral Education, 11(3): 191-202.

49. Lloyd, R (2008) Discretionary Effort \& the Performance Domain. The Australian \& New Zealand Journal of Organizational Psychology, 1, pp 22-34 DOI: 10.1375/ajop.1.1.22.

50. Lodahl, T.M. dan Kejner, M. (1965) "The definition \& measurement of job involvement", Journal of Applied Psychology, 49 (1): 24-33.

51. Lusch, R.F. \& Serpkenci, R.R. (1990), "Personal Differences, Job Tension, Job Outcomes, and Store Performance: A Study of Retail Store Managers," Journal of Marketing, 54 (January), 85-101.

52. Miller, K.I. \& Monge, P.R. (1986) Participation, satisfaction and productivity: a meta-analytic review. Academy of Management Journal, 29 (4): 727-753.

53. Morrison, E.W. (1994) Role Definitions \& Organizational Citizenship Behavior: The Importance of the Employee's Perspective. The Academy of Management Journal, 37 (6): 1543-1567

54. Moses, I. (2007). Institutional Autonomy Revisited: Autonomy Justified and Accounted. Higher Education Policy. 20: 261-274.

55. Odero, J.A., \& Makori, M.E. (2018) Employee involvement and employee performance: the case of part-time lecturers in public universities in Kenya. International Journal of Management and Commerce Innovations, 5 (2): 1169-1178.

56. Paullay, I.,M., Alliger, G.M., \& Stone-Romero, E (1994) Construct Validation of Two Instruments Designed to Measure Job Involvement \& Work Centrality. Journal of Applied Psychology, 79 (2): 224-228.

57. Phillips, E., Berg, M., Rodriguez, C., \& Morgan, D. (2010) A Case Study of Participatory Action Research in a Public New England Middle School: Empowerment, constraints and Challenges. American Journal of Community Psychology. 46(1): 179-194.

58. Porter L. W. \& Lawler III E. E (1968) Managerial Attitudes \& Performance. New York: McGraw-Hill.

59. Rabinowitz, S., \& Hall, D.T. (1977) Organizational Research on Job Involvement, Psychological Bulletin, 84 (2): 265-288. Robbins, S.P. \& Judge, T. A. (2013) Organizational Behavior (Fifteen Edition).Upper Saddle River: New Jersey, Pearson Prentice Hall.

60. Rinehart, J. S., \& Short, P. M. (1993). Job Satisfaction and Empowerment among Teacher Leaders, Reading Recovery Teachers, and Regular Classroom Teachers. Paper presented at the Annual Meeting of the American Educational Research Association (Atlanta, GA, April 12-16, 1993).

61. Rotenberry, P.F. \& Moberg, P.J (2007) Assessing the impact of job involvement on performance. Management Research News, 30 (3): 203-215 
62. Safari, A.S. (2015) Pengaruh Kualifikasi, Kompetensi, dan Rasio Dosen dan Mahasiswa Terhadap Kinerja Dosen Tetap Perguruan Tinggi Pariwisata di Kota Bandung. Disertasi. Program Studi Administrasi Pendidikan Sekolah Pascasarjana Universitas Pendidikan Indonesia, Bandung.

63. Shapira-Lishchinsky, O., \& Tsemach, S. (2014). Psychological empowerment as a mediator between teachers' perceptions of authentic leadership and their withdrawal and citizenship behaviors. Educational Administration Quarterly, 50(4): 675-712.

64. Shuck, B., Reio Jr, T.G., \& Rocco, T.S. (2011) Employee engagement: an examination of antecedent \& outcome variables. Human Resource Development International, 14 (4): 427-445

65. Short, P. M., \& Johnson, P. E. (1994). Exploring the links among teacher empowerment, leader power, \& conflict. Education. 114(4): 581-593.

66. Short, P. M., \& Rinehart, J. S. (1992). Empowerment within the school environment school participant empowerment scale: Assessment of level of. Empowerment within the school environment. Educational \& Psychological Measurement. 52(4): 951-961.

67. Spreitzer, G. M. (1995). Psychological Empowerment in the Workplace: Dimensions, Measurement, \& Validation. Academy of Management Journal, 38 (35): 1442-1465.

68. Stajkovic, A.D., \& Luthans, F., 1998. Self-efficacy and work-related performance: a meta-analysis. Psychological Bulletin, 124 (2): 240-261.

69. Steers, R.M., Mowday, R.T., dan Shapiro, D.L (2004) The future of work motivation theory. Academy of Management Review, 29 (3): 379-387

70. Sukirno, D.S. \& Siengthai, S (2011) "Does participative decision making affect lecturer performance in higher education?", International Journal of Educational Management, 25 (5): 494 - 508.

71. Suryaan (2018) Indonesian Private University Lecturer Performance Improvement Model to Improve a Sustainable Organization Performance. International Journal of Higher Education, 7 (1): 59-68.

72. Taylor, J. (2013). Goal setting in the Australian public service: Effects on psychological empowerment and organizational citizenship behavior. Public Administration Review, 73(3): 453-464.

73. Thomas, K., \& Velthouse, B. (1990). Cognitive element of empowerment: An interpretive model of intrinsic motivation. Academy of Management Review, 15 (4): 666-681.

74. Usop, A. M., Askandar, D. K., Langguyuan-Kadtong, M., \& Usop, D. A. S. O. (2013). Work performance and job satisfaction among teachers. InternationalJournal of Humanities and Social Science, 3(5): 245-252.

75. Uwes, S (2003) Manajemen Pengembangan Mutu Dosen. Jakarta: Penerbit Logos Wacana Ilmu.

76. Wiener, Y., \& Vardi, Y. (1980). Relationships between job, organization, and career commitments and work outcomes-An integrative approach. Organizational Behavior and Human Performance, 26 (1): 81-96.

77. Williams, L. J., \& Anderson, S. E. (1991) Job satisfaction \& organizational commitment as predictors of organizational citizenship \& in-role behaviors. Journal of Management, 17(3): 601-617.

78. Yoshimura, A. (1996). A Review \& Proposal of Job Involvement (Festschrift for Prof. Yoko Sano). Keio Business Review, 33, 175-184. 